\title{
Understanding the temporary appropriation in relationship to social sustainability
}

\author{
Jose Antonio Lara Hernandez \& Alessandro Melis
}

\begin{abstract}
This paper will review the relevant literature about the conceptualisation of the temporary appropriation within the urban environment. A vast review of theoretical and empirical texts reveals that despite the lack of a defined theory in this specific field, the temporary appropriation is a key concept for the understanding of people's sense of belonging to a place, and identity. The paper, therefore, attempts to fill the research gap through an extensive cross-disciplinary literature review that includes topophilia, space production, and environment and behaviour theories. Thus, the aim of the present writing is to frame, within the urban context, the relevance of the temporary appropriation in relation to social sustainability. To do so, it identifies and categorises the temporary appropriation into three main groups of activities featuring the urban landscape.
\end{abstract}

Keywords: Temporary appropriation, appropriation, urban sustainability, social sustainability

\section{INTRODUCTION}

The term appropriation was firstly introduced by Korosec-Serfaty in the Proceedings of the Strasbourg conference in 1976. Within the field of environmental psychology, the term appropriation is described as a temporary phenomenon that implies a dynamic process of interaction between the individual and its surroundings (KorosecSerfaty, 1976). It is a process similar to that of humanisation, which is the fundamental societal defined meanings interiorised by the individual (C. F. Graumann, 1976). Since then, several authors such as Purcell (2002), following Lefebvre's work, Pol Urrútia (2002) with his dual model, and Yory (2003) with the theory of topophilia, have used the term to explain the theoretical link between people and places. These authors consider the appropriation as an inborn necessity of humans that can be expressed through activities that occur in the urban landscape. Public spaces are an essential part of the urban landscape and their design is therefore strongly linked to the possibility of occurring activities related to the Temporary Appropriation (TA) (Noschis et al., 1978; Moudon, 1991; Madanipour, 1996). Thus, while appropriation is a broader term, its temporary variation refers more specifically to public spaces. Although there is conspicuous literature on the more general theme of appropriation, a phenomenon that refers to a lasting and consistent condition over the years (Díaz and Ortiz, 2003; Ramirez-Lovering, 2008; Ardura Urquiaga, 2014) and, even if less, on TA, that refers to non-permanent, daily or extemporaneous appropriation (Fonseca Rodriguez, 2015; Lara-Hernandez, Melis and Caputo, 2017). The accent in the latter has always been placed on the informality of this action. The present paper intends to focus on the TA instead as a consequence of the necessity of adapting human needs of a city that deprives the population of reference points due to sudden and unexpected changes. In this last case, the temporality of appropriation becomes an essential element of flexibility, the study of which, however, still constitutes a research gap. Hence, the present paper takes into consideration the assumption that the current conjuncture crisis due to the unstoppable growth of the cities imposes a reflection on their development in terms of sustainability (Lehmann, 2015), and therefore on the adaptation of the concept of appropriation with respect to the aforementioned phenomena of growth and change.

The following section describes the essence of appropriation as a concept in relation to the social nature of the human being and within the urban context as a citizen's right.

\section{APPROPRIATION}

The Oxford English Dictionary (2015) defines appropriation as the making of a thing private property. However, within the socio-urban design fields, the use of the term has no consensus and remains vague. For instance, some authors (Garcia Ramon, Ortiz and Prats, 2004; Ramirez-Lovering, 2008; Blanco, Bosoer and Apaolaza, 2014; Araya Diaz, 2016) use the term when referring to the illegal or informal use of the public space or territory by analysing their time occupancy, utilised design elements and their daily routes. Nevertheless, it is ambiguous to refer to the appropriation as both an illegal and informal use of the public space since it belongs to the citizens, and so does its 
use, and because for most of the governmental authorities, such as the Mexican ones, the informality is usually linked to informal commerce.

However, this text starts from the assumption that appropriation of the built environment is an inborn socio-spatial special need of the individual (Graumann, 1976; Yory, 2011). Lefebvre (1971) argues that the concept of appropriation is one of the most remarkable results that centuries of philosophical reflections have bequeathed. He describes appropriation as the goal of the social life by claiming that the domination of the natural environment without the appropriation tends to be absurd. Yory (2011), corroborates this argument by stating that we as humans are connaturally engaged with the construction-appropriation of our environment. Moreover, the concept of appropriation is embodied in his theoretical definition of topophilia as "the act of co-appropriation generated between the man and the world; through which the world becomes the world, at the opening realised by the man within its historic-spatial nature and human becomes human through its spatialisation" (Yory, 2011, p. 45).

Regarding the urban landscape, the appropriation can also be defined as the interaction between citizens and their city expressed through certain kinds of activities occurring in public spaces (Lara-Hernandez, Melis and Caputo, 2017). These activities contribute to the edifice of the social urban landscape, which is embedded in the second aspect of the right to the city. The Lefebvrian Purcell (2002), argues that the appropriation allows citizens to produce urban space rather than just to use the already produced urban space. The appropriation is what gives citizens the right to fully use and manage their everyday life within the urban environment (Lefebvre, 1992). Graumann (1976) contributes to reinforce that position by stating that the appropriation of the public space is a medium and a goal in order to overcome human alienation. Thus, it can be inferred that appropriation of space that is ephemeral and time framed could be understood as TA, in which the design of the built environment is necessary but not sufficient (Graumann, 1976). Along the same trajectory, Martinez (2014) emphasises that the TA relies on both the configuration of the built environment and the meanings and implicated relationships (people's values, behaviours and actions) of the social life in the city.

It follows that the TA is an individual, social, and spatial need that cannot be underestimated when it comes to urban studies.

\section{Temporary appropriation vs use of the space}

The previous section has highlighted the significance of the TA and its relevance to the urban context by establishing the bond between people and places: through a set of activities occurring in public spaces. However, the question of what these activities are is still pending. In a strict sense, when we use the public space, we are appropriating it, although it is just for a second. Torres (2009) considers the use and the appropriation of space to be similar concepts by claiming that as far as the individual exists, he is appropriating the space. Other authors (Pol and Iñiguez, 1996; Pol Urrútia, 2002; Vidal Moranta and Pol Urrútia, 2005; de la Torre, 2015) instead suggest that the use and the appropriation of the space are adjacent concepts, not similar though. They argue that the appropriation plays a key role to conform the urban identity through individual and collective activities in the urban environment, by claiming that the users only appropriate public spaces where they feel identified. This position is supported by studies done by Franck and Stevens (2007), whose interview results illustrate how regular users appropriate a specific area of a public space on a daily basis because they felt it to be comfortable.

A definition of the potential uses is provided by Fonseca Rodriguez (2015) when she describes the TA as "the temporary act in which people use public spaces to carry out individual or collective activities other than the purpose that the space was originally designed for." This definition helps, in fact, to distinguish between the activities related to the appropriation and the simple use of the space. One can see how this position is aligned with what Seghezzo (2009) calls persons, as one of the fifth dimensions of sustainability that will be discussed further, and differs from the definition used by Leary-Owhin (2015), and influenced by Lefebvre, that describes the TA as a time span condition by differential spaces in the urban context.

Nevertheless, not all the activities that a public space could host are a spatialised expression of the TA. One of the main challenges is in fact to identify the activities taking place in public spaces that are relevant for the phenomena according to their social, cultural and environmental context-specific nature. Consistently with scholars such as Crossa, Drummond, and Monnet, it is possible to group into three different categories the activities that can be considered as an expression of the TA: 
- Activities related to the economy (Crossa, 2009, 2016; Loukaitou-Sideris and Ehrenfeucht, 2009; Kim,

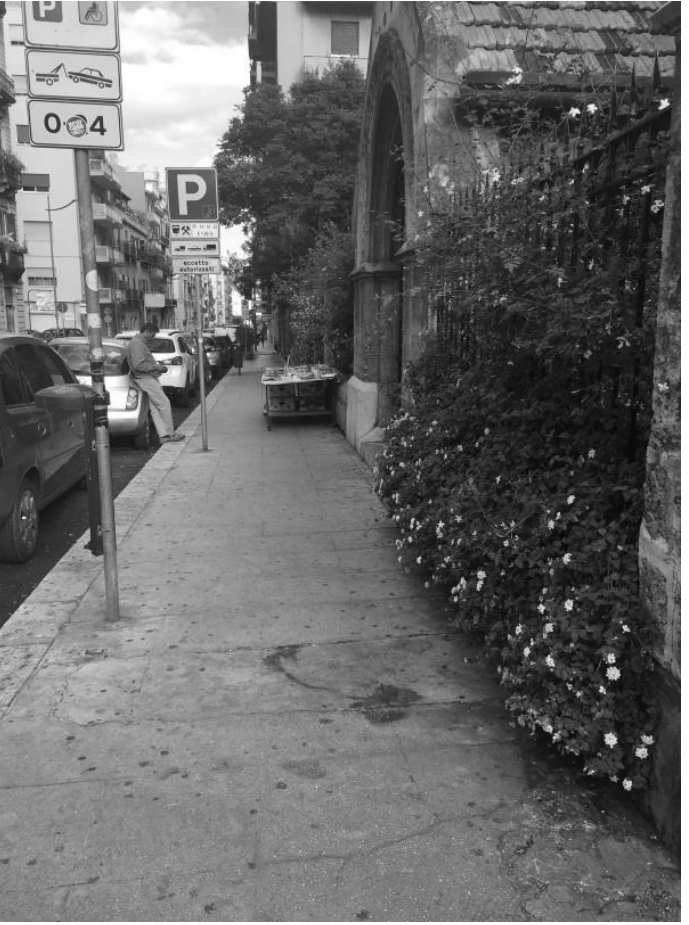

2013; de la Torre, 2015). See

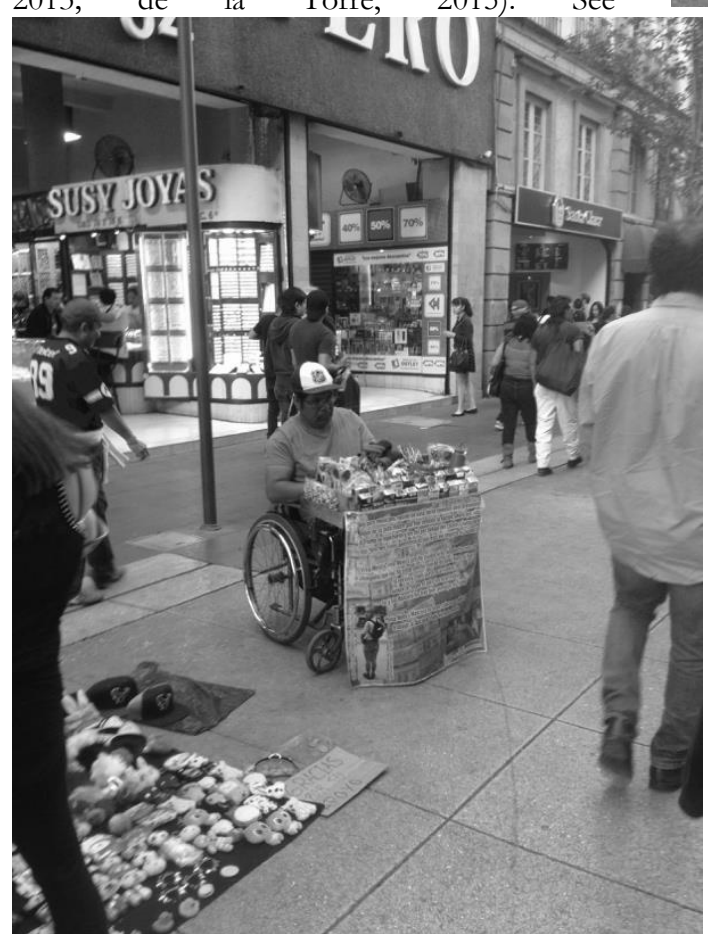

- $\quad$ Figure 1.

- Activities related to leisure such arts and sports (Drummond, 2000; MacDonald and Shildrick, 2007; Hernandez Mendo and Morales Sanchez, 2008; Díaz Larranaga, Grassi and Mainini, 2011; Simpson, 2011; 
Mouffe, 2014; Seaman and McLaughlin, 2014). See
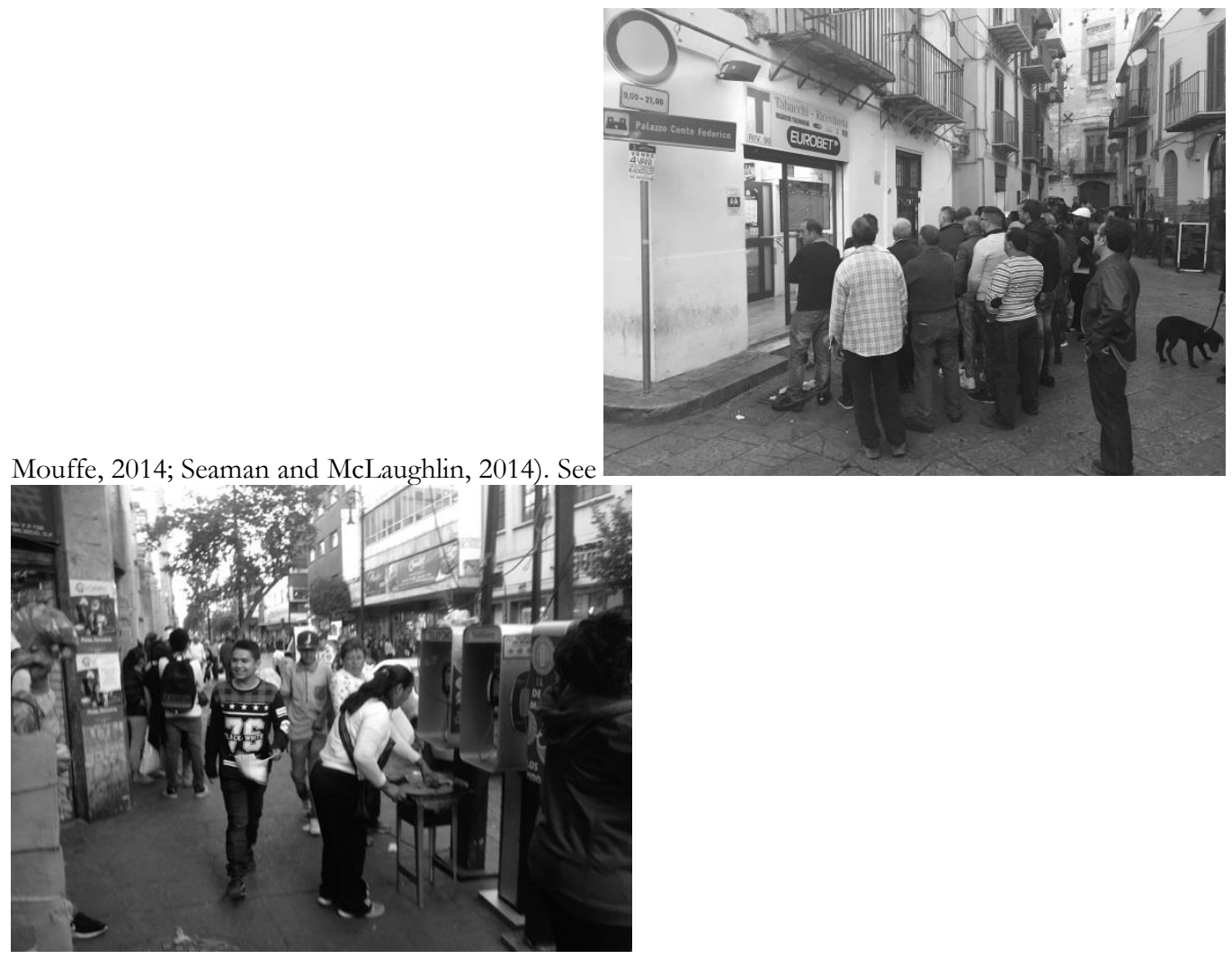

- $\quad$ Figure 2. 
- Activities related to sacralisation (Monnet, 1995; Portal, 2009). See

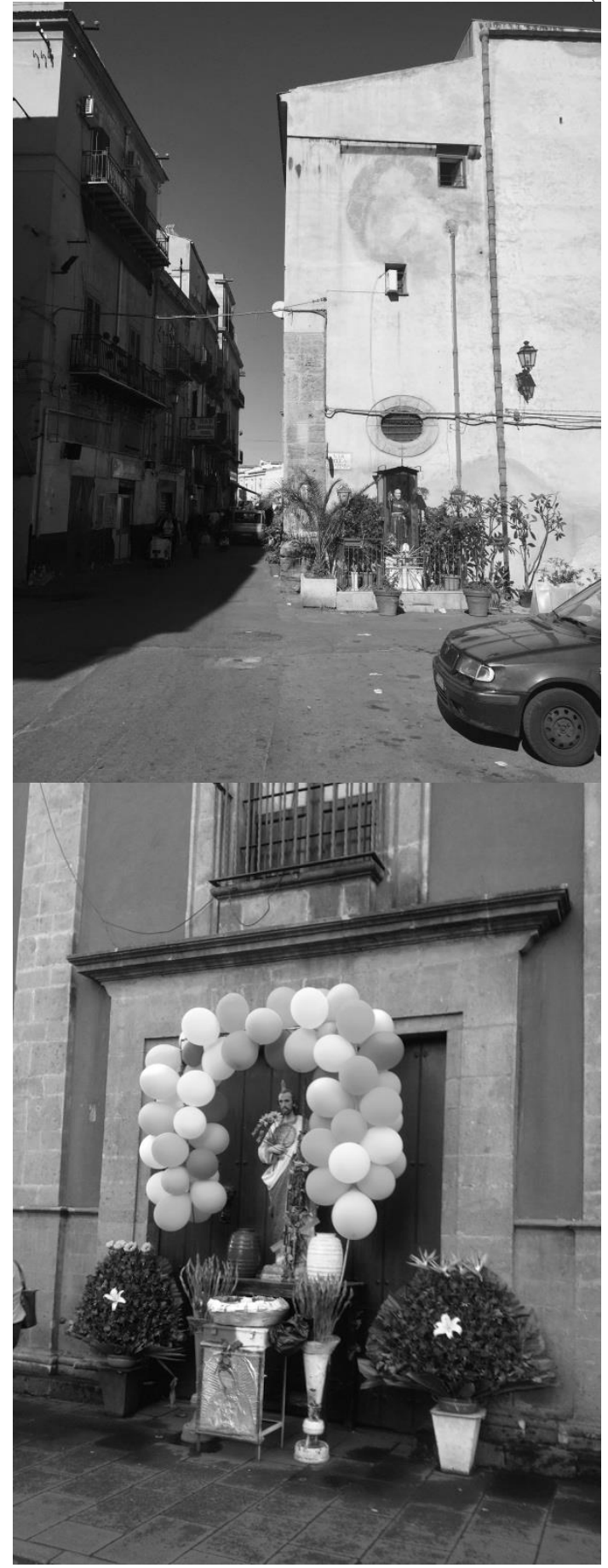

- $\quad$ Figure 3

Table 1 summarises the activities in which people temporary appropriate the public spaces.

Table 1:. Activities in the public space related to temporary appropriation (Source: Lara H., Melis, \& Caputo, 2017). 


\begin{tabular}{llllll}
\hline Description & $\begin{array}{l}\text { Any activity in which a person or group } \\
\text { use the public space in order to obtain } \\
\text { an economic benefit directly or } \\
\text { indirectly. }\end{array}$ & $\begin{array}{l}\text { Any activity in which a person or a group use } \\
\text { the public space for leisure purposes. }\end{array}$ & $\begin{array}{l}\text { Any activity in which a } \\
\text { person or a group use the } \\
\text { public space for religious } \\
\text { purposes. }\end{array}$ \\
\hline Sub-category & Work & Trade & Sports-games & $\begin{array}{l}\text { Artistic } \\
\text { expressions }\end{array}$ & Rest \\
\hline $\begin{array}{l}\text { Individual or } \\
\text { collective }\end{array}$ & $\begin{array}{l}\text { Advertising or } \\
\text { promoting services, } \\
\text { waiting, engaging or } \\
\text { attracting possible } \\
\text { clients. }\end{array}$ & $\begin{array}{l}\text { Selling or buying } \\
\text { products (food, } \\
\text { handicraft, } \\
\text { clothes, etc.) }\end{array}$ & $\begin{array}{l}\text { Skateboarding, } \\
\text { soccer, cards, } \\
\text { marbles, } \\
\text { hopscotch. } \\
\text { dancing, painting, } \\
\text { acrobatics, } \\
\text { reciting and } \\
\text { singing. }\end{array}$ & $\begin{array}{l}\text { Eating, } \\
\text { resting }\end{array}$ & $\begin{array}{l}\text { Processions, praying candles and } \\
\text { putting flowers. }\end{array}$ \\
\end{tabular}
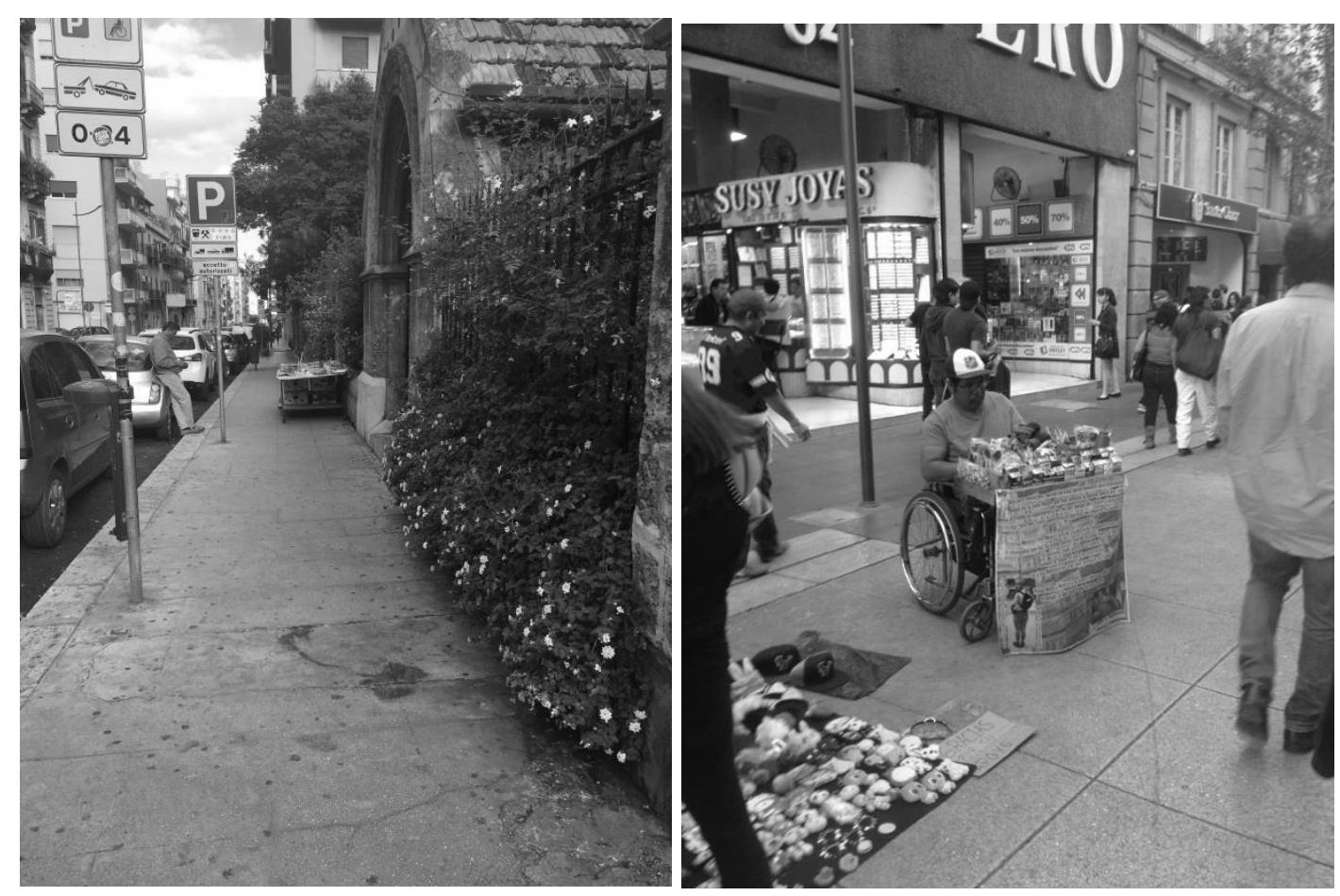

Figure 1: (left) Man selling in streets in Palermo City Centre; (right) Man selling candies in Mexico City Centre (Source: Authors).
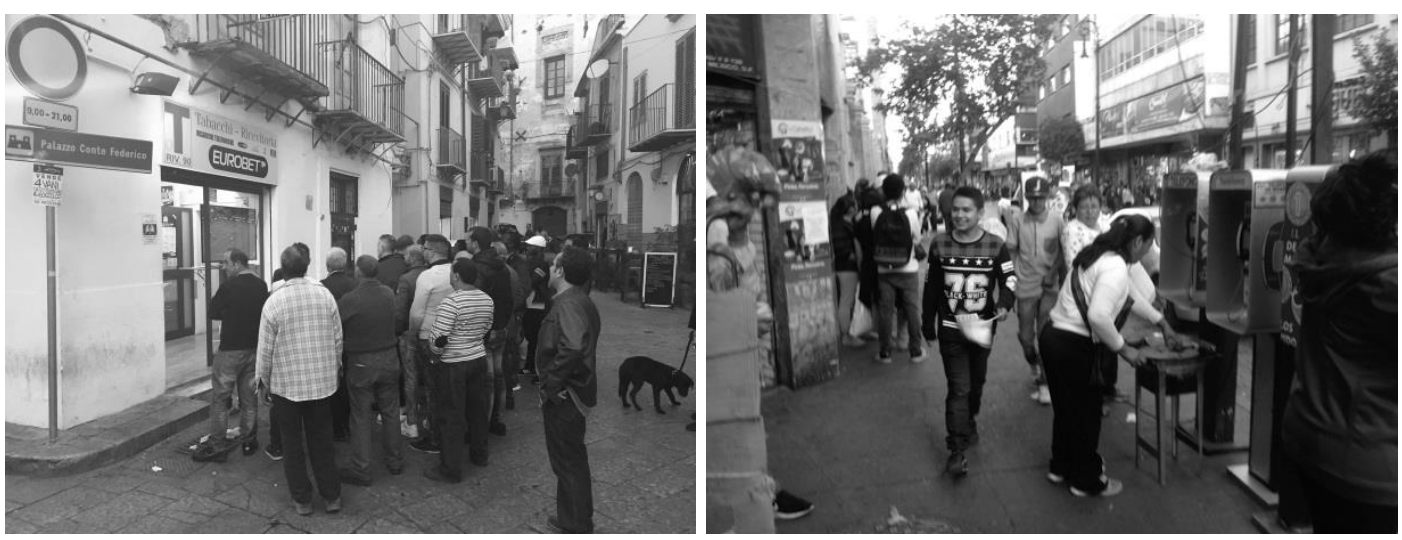

Figure 2: (left) Men watching football match in the street in Palermo City Centre; (right) Woman cooking in street in Mexico City Centre (Source: Authors). 

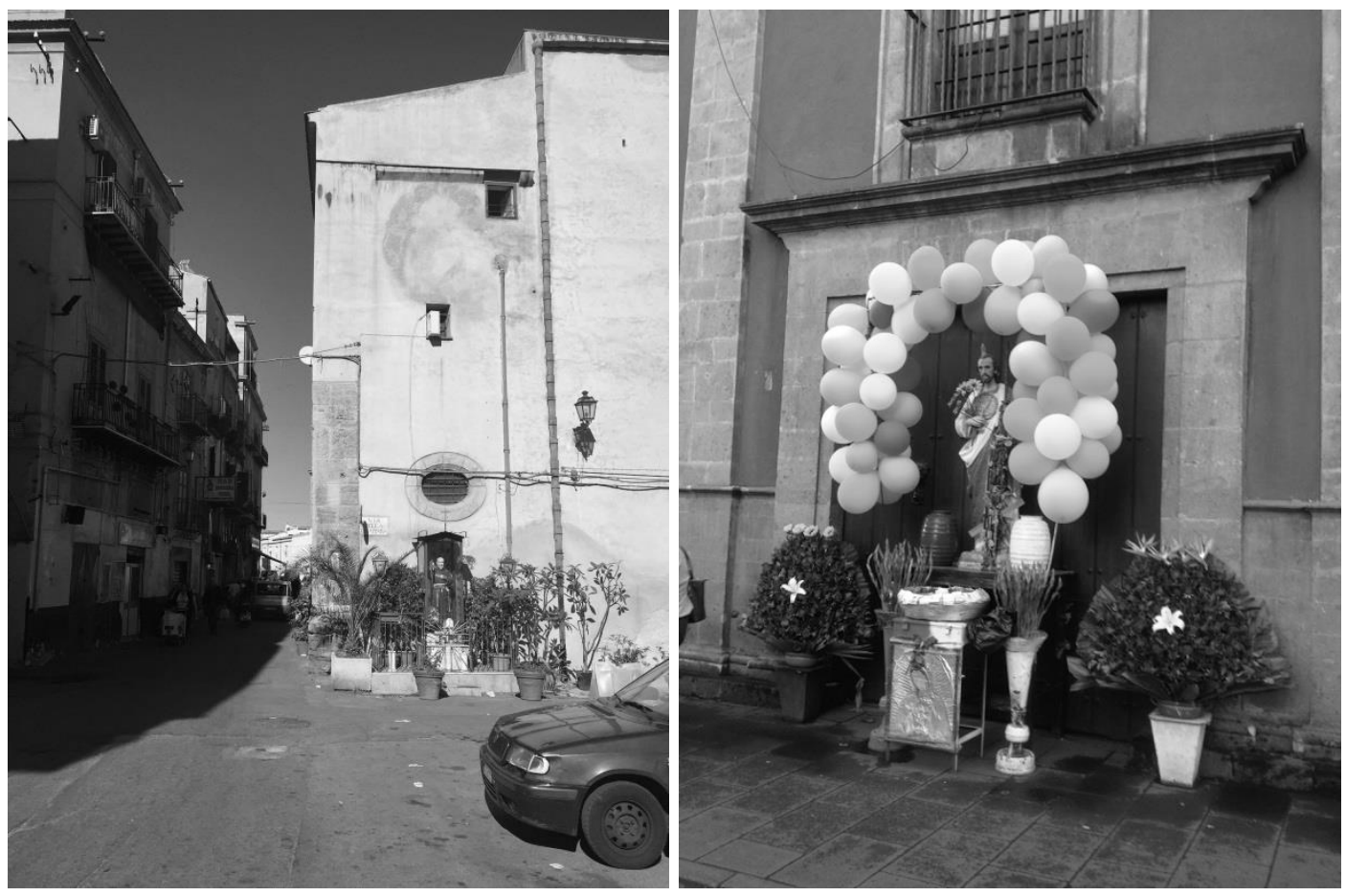

Figure 3: (left) Altar in street in Palermo City Centre; (right) Altar in street in Mexico City Centre (Source: Authors).

\section{Temporary appropriation and place}

Although in theory, every space could be temporarily appropriated. It is not clear, however, which spaces are suitable to be appropriated or why. Within this context, Franck and Stevens (2007) have introduced the definition of "loose space" which is strongly related to people's perception of the potential activities suitable for a certain public spaces. They argued that an urban public space can only become loose when people recognize the possibilities in it and utilize those possibilities for their own will, carrying out different activities which are not originally intended for those locations. The possibility, diversity and disorder are the most remarkable virtues of the loose space. Even if the novelty of the looseness of public space is highly relevant worldwide, the activities that make the loose space emerge could be broad and not specifically the categories that characterise the TA. The TA seems to occur in what Relph (1976) defined as place, which is a centre of action; a blend of human and natural realms and the core of our prompt experiences of the world. In other words, place is a part of space occupied by a person or a thing and it is endowed with meaning and cultural value (Madanipour, 1996). This meaning refers to the symbolic and imaginary attributes that people have about a determinate place, building or urban element and what they represent for them (Rapoport, 2005). Moreover, the place is embodied by the cultural landscape in which the individual plays a key role in its conformation (Hubbard et al., 2002; Seghezzo, 2009). This view is supported by several authors such as Graumann (1976, 1983), Pol Urrútia (2002), Vidal Moranta (2005) and Martinez (2014), that claim that people temporary appropriate public spaces where they feel identified or somehow represented by. In addition, researchers of environmental psychology, such as Vidal Moranta and Pol Urrutia (2005) argue that the place that is appropriated is considered as a factor of continuity and stability of the self, in parallel to another factor that contributes to the identity and group cohesion. In conclusion, the TA takes place in urban public spaces in which an individual or group of individuals feels culturally identified.

\section{Temporary appropriation and culture}

As stated in the previous paragraph, the TA is activated by the sense of belonging whose nature is predominantly cultural. However, the term culture is subject to different interpretations depending on the discipline. The Cambridge Dictionary (2018) defines culture as "the way of life, especially the general customs and beliefs, of a particular group of people at a particular time". The Oxford English Dictionary (2018) defines culture as: 1) the arts and other manifestation of human intellectual achievement regarded collectively, 2) the ideas, customs, and social behaviour of a particular person or society. Bonfil Batalla (2004) proposes a broader definition, stating that culture means the group of symbols, values, attitudes, skills, knowledge, meanings, communication ways, social structure and physical objects that make possible the life of a determinate society. Also, they allow the transforming and reproducing of the 
culture through next generations. Although culture is a vast domain, we can imply that the built environment is part of it, a subset of it. Moudon (1991) claims that the built environment is a high-pitched display of cultural specificity by claiming that each type of society generates a particular behaviour and it is reflected in the way they use the space through activities. For instance, in the Netherlands, the boundaries between people's public and private lives are very strict and public space is the space of strangers, for the spontaneous and superficial gather (Haan, 2005), while in Mexico the public spaces are constantly temporary appropriated and these boundaries could be blurred or overlapped (Monnet, 1995). Within the afforded mention subset, there are system of activities and system of settings, in which the design configuration of the space plays an important role. According to Rapoport (1998) any activity occurring in public spaces (including TA) can be dismantled into four elements; the activity itself, the way which the activity is carried out, how it is associated with other activities and combined into activity systems and the meaning of the activity. Kyle et. al (2014) imply that activities which occur in the urban space constantly repeated over certain periods of time help to construct the identity and bonding between place and individuals. These activities appearing in a more or less harmonious manner, each one of them pursued by its own individual sake, is what produces culture (Eliot, 1949). Thus, we can infer that culture is a dynamic condition in which activities over time attain culture, but these activities also are a reflection of any specific culture.

In this respect, the appropriation relates to the social sustainability as initially defined in the Brudtland report (1987). Hence, within the urban context, urban social sustainability aims to not compromise the social needs that the built environment can satisfy for future generations. Consequently, the aim of this paper is to illustrate and explain the relationship between these two concepts, the TA and social sustainability on their theoretical and practical basis. The following section illustrate the concept of social sustainability within the urban scenario.

\section{URBAN SOCIAL SUSTAINABILITY}

The previous paragraphs described the three main groups of activities that characterise the TA in the public spaces as a spatialised expression and described where the TA occurs, and its relationship with the conceptualisation of culture. Following the Brundtland report (1987), several scholars (Lozano, 2008; Dixon et al., 2009; Seghezzo, 2009; Dempsey et al., 2011; Woodcraft, 2012) refer to the aforementioned relationship as core aspects of the social and environmental sustainability. The present section will therefore focus on the social sustainability concept within the urban context and illustrates its relationship with the ideas already expressed.

According to Brundtland's three pillars of sustainable development, several authors, such as Constanza (1992), Kleine (2009), Munasinghe (1993) and Spindler (2011) have provided a number of definitions for Environmental, Economic, and Social Sustainability. However, Seghezzo (2009) suggests that this triad provides a narrow perspective because it overestimates the explanatory power of economic reasoning and it does not pay attention to fundamental aspects of development. In turn Vallance et. al. (2011) also argue that sustainable social development should be addressed first rather than the environmental or economic. In this regard, they have introduced a category of three different groups in which advocates of social sustainability within the urban context have discussed the topic. This categorisation comes as follows: first, development social sustainability that deals with issues ranging from access to fresh water and food, medicines and shelter to equity and justice. It is expected that the benefits for the environment will come once these basic needs are satisfied, that is a similar argument to Maslow's hierarchy (1943). Second, bridge social sustainability, which seeks to identify the social conditions needed in order to support ecological sustainability. These conditions are classified into two main groups, the transformative approaches, which re-think the relationship between people and environment by challenging fundamental ideas about how the environment is socially constructed, and the nontransformative, which propose to do things in a different manner without an ideological change in society, such as the use of technology, i.e. the use of electric cars. Lastly, maintenance social sustainability which is burden in socio-cultural predilections and attributes and the environment are preserved over time. However, in this arrangement the concept of social sustainability is under the scope of aiming to create social consciousness towards the impacts of human actions on the natural environment, rather than conceptualise how the socio-cultural fabric could be sustainable. Moreover, this arrangement does not recognise the spatial needs of the individual because the human component is represented by society as a whole.

Social sustainability within the urban context aims to not compromise the social needs that the built environment can satisfy for future generations. It is a combination of designing both physical and social realms, infrastructure to support social and cultural life (Woodcraft, 2015). Dempsey et. al. (2011) argued that social sustainability within the urban context strongly relies on two main aspects: social equity and sustainability of community. The first aspect is frequently associated and measured by the accessibility to key facilities that satisfy basic needs within a determinate area (Burton, 2000; Barton, 2002). Nevertheless, social equity is also commonly associated with the inclusion of all members of society without distinction, in which the citizen's appropriation of the public realm is seen as an alternative to mitigate urban segregation and social exclusion (Pol, 2002). The second aspect is frequently related to the formation of community and its level of social interactions between people, in which he points out that people living in a determinate area that do not socially interact between them are not a community, they are just people living 
separate lives with little sense of pride or place attachment (Dempsey, 2006). Studies carried out by Seaman and McLaughlin (2014) suggest that the more interaction between individuals and their outdoor environment, the higher levels of place attachment and sense of community. Lofland (1998), in her seminal book, describes the relevance of the social territory within the urban environment by claiming that the public space in the city is where the public realm is created. Thus, following both arguments, we can imply that the same occurs in the relationship between people and their built environment, meaning that people who do not interact (or are deprived from interactions) with their public spaces within their cities might not be called citizens.

Returning briefly to the pillars of sustainability, other researchers such as Valentin \& Spangenberg (2000), Hawkes (2001), Deakin et. al. (2007) and Lozano (2008) have added a fourth pillar. This new added pillar strives basically on two main concepts, which are governance and culture, with other featured variations such as justice and well-being (Ali-Toudert and Ji, 2017). Also, Musacchio (2009) proposes a model to achieve sustainability based on six concepts, she calls them the six Es, which are aesthetics, environment, ethics, equity, experience and economy. On the one hand, these sustainability models could be applied to conceptualise different urban scales such as region, city and neighbourhood, since they all recognise the importance of the social realm. On the other, they fail due to the fact that they acknowledge the social realm as being represented by society as a whole and not as a set of individuals which is the level of public space. Furthermore, none of them take into account the value of time, since sustainability is dynamic rather than a static state (Antrop, 2005). Thus, under this view, the quintet proposed by Seghezzo (2009) is more accurate because it is formed by "place, permanence and persons" in which place stands for three-dimensional physical and geographical but also a cultural landscape, permanence is referred to the temporal dimension, and lastly persons, as the individual's part of a society. Figure 4 illustrates the model already described.

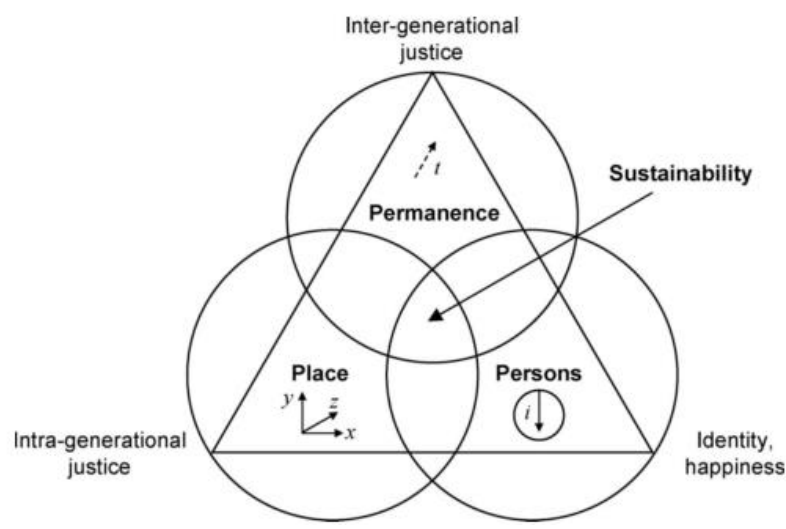

Figure 4: The five-dimensional sustainability triangle. Source: Seghezzo, 2009.

Thus, urban social sustainability could be interpreted as an umbrella term that encompasses the economic, social and environmental realms of cities. It is a way in which cities and societies are organised in order to accommodate the needs of the current and future generations without compromising the ecological environment (Vojnovic, 2014). As explained earlier this combination involves the design physical and social realms (Woodcraft, 2015). Capel Saez (2002) implies that the social and the physical realm are elements of the urban landscape. Antrop (2005) supports this argument by emphasising that the urban landscape is the overlapping of landscapes, such as cultural and architectural landscapes which are in constant change because they are the dynamic expression of interaction between cultural and natural forces in the environment. Moreover, according to Musacchio (2009), the urban landscape is a system that is re-shaped constantly by people according to their necessities. Also, she claims that the heterogeneity of a designed landscape such as public spaces, is influenced spatially and functionally by people's values, behaviours and actions, thereby through appropriation.

\section{Urban sustainability and culture}

As mentioned earlier, Seghezzo (2009) argues that sustainability has five dimensions; place, permanence and persons. The first three dimensions corresponds to the place, as explained earlier is the space where the identity of the place and the cultural values are transmitted. Researchers in the field of culture, such as Rapoport (1998), Kent (1990), Holahan and Bonnes Dobrowolny (1979) argued that a place could be defined by the activities of individuals that occur in it and many of those may defy the passing of time, thus emphasising the theoretical link between place, the person and time through particular activities occurring constantly. In addition, the latter leads us to the second dimension which is permanence. It adds the value of time to the concept of place because places are in essence culturally constructed and related to events or things that occurred at various, sometimes remote points in history. Advocates of design and 
behaviour studies such as Lawrence and Low (1990) argue that time plays an important role, and should be taken into consideration to understand the different dimensions of the space (e.g. spatial, cultural, social, personal). Lastly, the dimension of persons which stress the individual as a part of the society rather than over impose the concept of society as a whole without an individual recognition. This awareness of the individual entity within its close relationship with the concept of place are aligned to Graumann's definition of appropriation already mentioned in the INTRODUCTION section. Thus, by adding the dimension of time, this suggests a strong link may exist between the concept of TA and urban sustainability.

\section{Urban sustainability studies}

Studies with focus on social sustainability have been accomplished at different urban scales. For instance, Forman (1997), Wheeler (2000), Knippenberg (2007), Cuthill, (2010) at regional level; Girardet (1999), Nijkamp and Perrels (1994), Roseland (1997) Dempsey et. al. (2011), Dixon et. al. (2009), Burton (2000), Yiftachel \& Hedgcock (1993) and Sharifi \& Murayama (2013) at the city level; Pongmas (2004), Chiu (2003), Ancell \& Thompson-Fawcett (2008), Bramley \& Power (2009), Opp (2017) and Raman (2010) at neighbourhood level. However, authors (Mehan and Soflaei, 2017; Shirazi and Keivani, 2017) argue that studies focused on urban social sustainability at the microscale level (public space) are the less explored. For instance, studies focussed on squares exploring strategies for regeneration aiming to achieve social sustainability (Mehan, 2016) and studies focused on determining the social function of the square (Harun et al., 2014). Mehan (2016) concludes that the preservation of the historical identity is one of the major contributing approaches of urban regeneration strategies to achieve social sustainability in public squares with historical value. Results of a multi-layered study by Harun, Zakariya, Mansor, \& Zakaria (2014) suggest that a high diversity-range of activities in which people temporarily appropriate the public space contributes to the social sustainability of the site. Hence, the physical dimension of the environment and the TA of the public space are associated with social sustainability. Mehan and Soflaei (2017) attempted to link theory and practice in the social sustainability field by incorporating Maslow's hierarchy of human needs into the urban environment. They argue that spatial qualities of the design of the built environment can be made in reflecting these needs. Table 2 summarises their claims.

Table 2: Translation of the human needs to spatial qualities in an urban context. Source: Mehan and Soflaei (2017)

\begin{tabular}{ll} 
Human Needs Residents & Spatial Qualities in Urban Design \\
\hline Physiological Needs & Comfort/Public Services/Firmness and Balance \\
\hline Safety Needs & Privacy/Legibility/Safety \\
\hline Belongingness/Love Needs & $\begin{array}{l}\text { Social Amenities/Social Facilities/Sense of Place } \\
\text { and Identity }\end{array}$ \\
\hline Esteem Needs & $\begin{array}{l}\text { Inclusiveness/Preservation of the Local } \\
\text { characteristics }\end{array}$ \\
\hline Self-Actualization Needs & Diversity/Public Participation \\
\hline Beauty Needs & Visual Richness/Visual Proportions/Visual \\
& Distinctiveness \\
\hline
\end{tabular}

Despite this attempt, Maslow's theory has a fundamental critique. First, it has been argued that Maslow's theory only applies to pluralistic societies (Western) which make it culture-specific rather than universal in the application (Neher, 1991). Secondly, in advanced societies, the first two steps of Maslow's needs are often satisfied, whereas the following steps (love and self-esteem) represent a challenge; contrary to what occurs in simpler societies (Turnbull, 1974). Therefore, it could be risky to apply such an approach in cities that hold a multi-diverse and ancient cultural background, such as Latin American, Mediterranean or Asian cities.

\section{THE MISSING LINK}

The previous sections explain how TA and urban social sustainability are interrelated concepts, in which the cultural factor plays a determinant role. Figure 5 summarises and illustrates this relationship deeply. Firstly, the diagram highlights in colours different research fields that have approached both concepts ranging from architecture (also includes urban planning, landscape and urban design), to environmental sciences and social sciences. Secondly, it identifies the different type of sources based on their relevance for the purpose of this text such as: key paper, seminal paper and theory. Lastly, it shows the links between the different sources and their relevance for the present paper, the darker colour of the name and symbol the more pertinent for this research. 

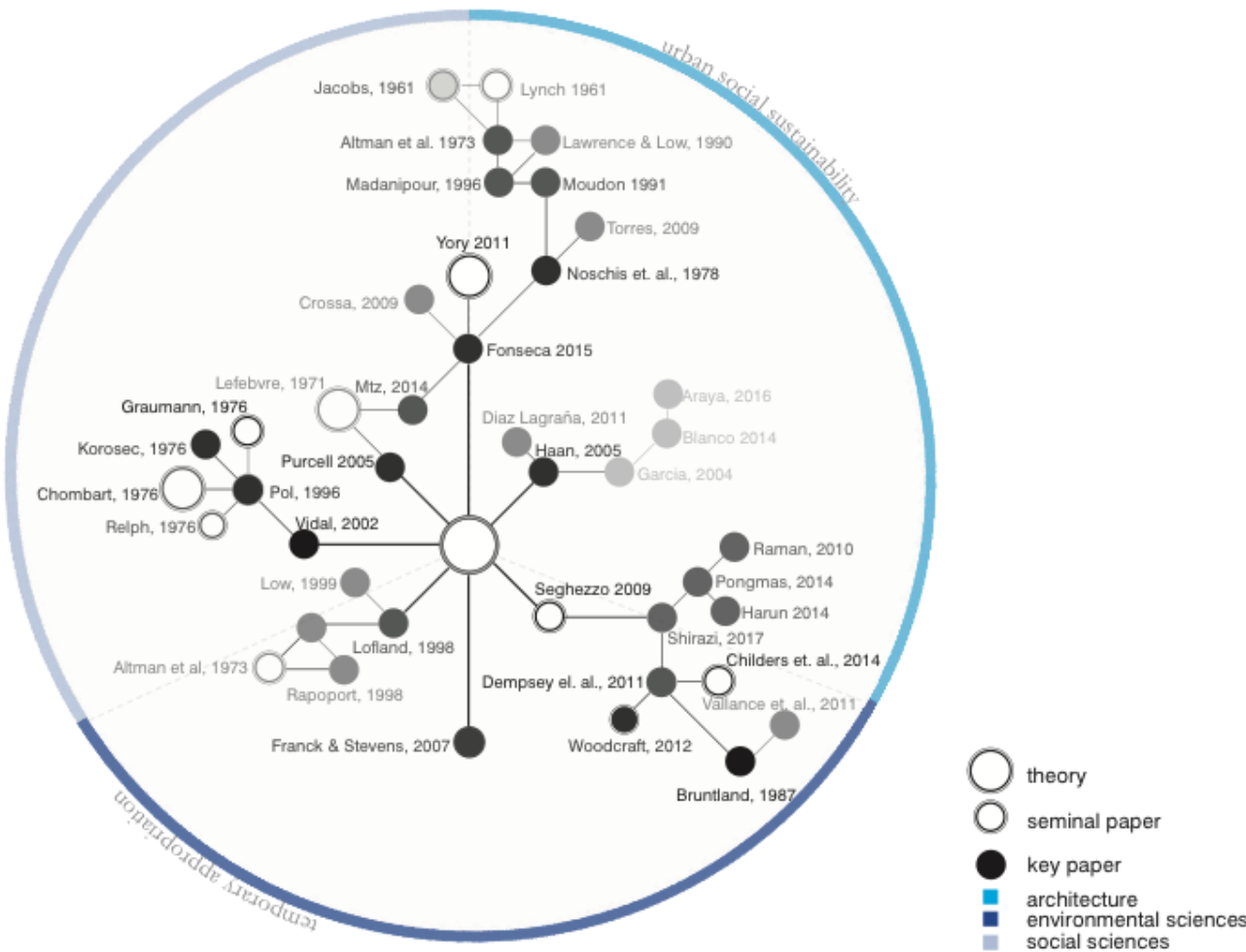

Figure 5: Temporary appropriation and urban social sustainability diagram

\section{DISCUSSION AND CONCLUSION}

An initial objective of this paper was to illustrate the relationship between two complementary concepts, the TA and the social sustainability. The first section has discussed the relevance of the TA for the social construction of the urban landscape. It has been explained that the TA occurs in public spaces with meanings and values being socially constructed, which are places. In addition, it has categorised drivers into three main groups by illustrating examples from different cities and cultures. It has been pointed out that the dynamic and reciprocal condition between TA and culture, in which the value of time plays a key role for its formation, transition and preservation of cultural values within the urban environment.

The second section established urban social sustainability as one of the key concepts for sustainable development. Social sustainability is cross-disciplinary, multidimensional and strongly correlated with other aspects of the built environment, such as design. Moreover, the complexity of the multidimensional concept allows for the developing of case-specific and place-specific research, which suggests that each study focussed on social sustainability should be specific for every particular context. Several authors (Kates et al., 2001; Clark and Dickson, 2003; Antrop, 2005) have claimed that the study of sustainability will be benefited from multidisciplinary approaches such as the one presented here. Hence, the study of the TA of public space is context specific since it is strongly related to the social aspect of the urban landscape, and social aspects are essentially scale-based studies. Moreover, the improvement and maintenance of the physical dimension of the environment are widely accepted as a strategy to achieve social sustainability.

However, further studies need to be carried out in this field of research. This paper has argued that there is a strong link between the TA and social sustainability. It has been proved to be a complementary relationship, as previously illustrated in Figure 5. In addition, it has identified that the TA of public spaces is a phenomenon that plays a key role in the urban dynamics by contributing to the construction of the social landscape of the city. Moreover, the processes of the social landscape in a city a strongly linked to the resilience of an urban environment (Childers $e t$ al., 2014). In general, therefore, it seems that the design of public spaces has implications towards the TA. We agree with researchers such as Kates et. al. (2001) and Clark \& Dickson (2003) to push further the need of studies about human transformation as essential to the science empirical agenda for the common interest.

Overall, this study strengthens the idea that the TA could be an indicator to assess the urban social sustainability in any specific context. These findings have significant implications for the understanding of how the design of the built 
environment could have the capability to allow the TA for future generations, which is one of the main aims of the urban sustainability. This work contributes to existing knowledge of social sustainability by providing the TA as a medium to study the urban landscape at the scale of the public spaces. Within the field of architecture (landscape, urban design and planning), more information on the design features of the built environment related to the TA in any determinate context would help us to establish a greater degree of accuracy on this matter. The scope of this study was limited in terms of urban scale due to it being focused at the level of the streetscape. In terms of direction for further research, further work could be focussed in other urban scales such as neighbourhood, districts and cities. It would be interesting to identify and categorise the TA in cities with different cultural characteristics and weather conditions than the ones illustrated here. It will be interesting to assess the effects of TA in relation to well-being, sense of community or even crime perception. There is, therefore, a definite need for a deep understanding of the TA and its relationship with the sustainability of any socio-cultural landscape.

\section{REFERENCES}

Ali-Toudert, F. and Ji, L. (2017) 'Modeling and measuring urban sustainability in multi-criteria based systems — A challenging issue', Ecological Indicators. Elsevier Ltd, 73, pp. 597-611. doi: 10.1016/j.ecolind.2016.09.046.

Ancell, S. and Thompson-Fawcett, M. (2008) 'The social sustainability of medium density housing: A conceptual model and christchurch case study', Housing Studies, 23(3), pp. 423-442. doi: 10.1080/02673030802029990.

Antrop, M. (2005) 'Why landscapes of the past are important for the future', Landscape and Urban Planning, 70(70), pp. 21-34. doi: 10.1016/j.landurbplan.2003.10.002.

Araya Diaz, D. F. (2016) 'Propiedad y apropiación', in Contested Cities. Madrid, España.

Ardura Urquiaga, Á. (2014) 'Madrid. Espacio público confiscado. La privatización y resignificación del espacio público en los procesos de transformación material de las plazas del centro de Madrid', Scripta Nova. Revista Electrónica de Geografia y Ciencas Sociales. Available at: http://www.ub.edu/geocrit/coloquio2014/Alvaro Ardura Urquiaga.pdf.

Barton, A. C. (2002) 'Urban Science Education Studies: A Commitment to Equity, Social Justice and a Sense of Place', Studies in Science Education, 38(1), pp. 1-37. doi: 10.1080/03057260208560186.

Blanco, J., Bosoer, L. and Apaolaza, R. (2014) 'Movilidad, apropiación y uso del territorio: una aproximación a partir del caso de Buenos Aires', Scripta Nova. Revista electrónica de geografia y ciencias sociales, XVIII(493).

Bonfil Batalla, G. (2004) 'Pensar nuestra cultura', Dialogos de accion, primera etapa, pp. 117-134.

Bramley, G. and Power, S. (2009) 'Urban form and social sustainability: The role of density and housing type', Environment and Planning B: Planning and Design, 36(1), pp. 30-48. doi: 10.1068/b33129.

Brundtland, G. H. (1987) World commission on environment and development (1987): Our common future, World Commission for Environment and Development. Oxford University Press.

Burton, E. (2000) 'The potential of the compact city for promoting social equity', in Burton, E., Jenks, M., and Williams, K. (eds) Achieving sustainable urban form. New York, US: Routledge, pp. 19-29.

Cambridge English Dictionary (2018) Culture meaning in the Cambridge English Dictionary. Available at: https://dictionary.cambridge.org/dictionary/english/culture (Accessed: 22 January 2018).

Capel Sáez, H. (2002) La morfología de las ciudades. Barcelona, España: Ediciones del Serbal.

Childers, D. L. et al. (2014) 'Advancing urban sustainability theory and action: Challenges and opportunities', Landscape and Urban Planning. Elsevier B.V., 125, pp. 320-328. doi: 10.1016/j.landurbplan.2014.01.022.

Chiu, R. L. H. (2003) 'Social sustainability, sustainable development and housing development: the experience of Hong Kong', in Forrest, R. and Lee, J. (eds) Housing and social change: East-west perspectives. London, UK: Routledge, p. 221.

Clark, W. C. and Dickson, N. M. N. (2003) 'Sustainability science: the emerging research program', Proceedings of the National Academy of Sciences of the United States of America, 100(14), pp. 8059-61. doi: 10.1073/pnas.1231333100.

Costanza, R. (1992) Ecological economics: the science and management of sustainability. Columbia University Press.

Crossa, V. (2009) 'Resisting the Entrepreneurial City: Street Vendors' Struggle in Mexico City's Historic 
Center', International Journal of Urban and Regional Research, 33(1), pp. 43-63. doi: 10.1111/j.14682427.2008.00823.x.

Crossa, V. (2016) 'Searching for order on the "dirty" streets of the city. Displacement of street vendors in colonial and postcolonial Mexico City', in Contested Cities. Madrid, España.

Cuthill, M. (2010) 'Strengthening the "social"in sustainable development: Developing a conceptual framework for social sustainability in a rapid urban growth region in Australia', Sustainable Development. Wiley Online Library, 18(6), pp. 362-373.

Deakin, M. et al. (2007) Sustainable urban development volume 2: the environmental assessment methods. Routledge.

Dempsey, N. et al. (2011) 'The Social Dimension of Sustainable Development: Defining Urban Social Sustainability', Sustainable Development, 19(May 2009), pp. 289-300. doi: 10.1002/sd.417.

Díaz, F. and Ortiz, A. (2003) 'Ciudad e Inmigración: Uso y Apropiación del Espacio Público en Barcelona', pp. 399-407. Available at: www.cervantesvirtual.com/.../ciudad-e-inmigracin-uso-y-apropiaci...

Díaz Larrañaga, N., Grassi, L. and Mainini, C. (2011) 'Socialidad: Los modos de apropiación del espacio público', Question, 1(29), p. 12. Available at:

http://perio.unlp.edu.ar/ojs/index.php/question/article/view/572/849.

Dixon, T. et al. (2009) 'Measuring socially sustainable urban regeneration in Europe', Oxford Institute for Sustainable Development (OISD) and European Investment Bank (EIB).

Drummond, L. (2000) 'Street Scenes: Practices of Public and Private Space in Urban Vietnam', Urban Studies, 37(12), pp. 2377-2391. doi: 10.1080/00420980020002850.

Eliot, T. S. (1949) Notes Towards the Definition of Culture. Available at: https://books.google.co.uk/books?id=QYR9FNyKMmwC.

Fonseca Rodriguez, J. M. (2015) 'La importancia y la apropiación de los espacios públicos en las ciudades', Revista de Tecnologia y Sociedad, 4(7), pp. 1-11.

Franck, K. A. and Stevens, Q. (2007) Loose Space: Diversity and Possibility in Urban Life. New York, US: Routledge.

Garcia Ramon, M. D., Ortiz, A. and Prats, M. (2004) 'Urban planning, gender and the use of public space in a peripherial neighbourhood of Barcelona', Cities, 21(3), pp. 215-223. doi: 10.1016/j.cities.2004.03.006.

Graumann, C. (1983) ‘On Multiple identities', International Social Science Journal, pp. 309-321. Available at: http://eds.b.ebscohost.com/eds/pdfviewer/pdfviewer?sid=4e7bdb42-733e-4fbb-98b0-

3082b60477c5\%40sessionmgr105\&vid=7\&hid $=112$.

Graumann, C. F. (1976) 'The concept of appropriation (aneignung) and modes of appropriation of space'. Universitat Heidelberg, pp. 301-313. Available at: http://iaps.scix.net/cgi-

bin/works/Show?iaps_00_1976_009.

Haan, H. De (2005) 'Social and Material Appropriation of Neighborhood Space : Collective Space and Resistance in a Dutch Urban Community', October, pp. 1-122.

Harun, N. Z. et al. (2014) 'Determining Attributes of Urban Plaza for Social Sustainability', Procedia - Social and Behavioral Sciences. Elsevier B.V., 153, pp. 606-615. doi: 10.1016/j.sbspro.2014.10.093.

Hawkes, J. (2001) The fourth pillar of sustainability: Culture's essential role in public planning. Common Ground.

Hernandez Mendo, A. and Morales Sanchez, V. (2008) 'Una revisión teórica: ocio , tiempo libre y animación sociocultural', Efdeportes.com, pp. 9-12. Available at: http://www.efdeportes.com/efd127/una-revisionteorica-ocio-tiempo-libre-y-animacion-sociocultural.htm.

Hubbard, P. et al. (2002) Thinking Geographically. London, UK: Continuum. Available at: http://books.google.ch/books?id=RsnnsltFeS0C.

Kates, R. W. et al. (2001) 'Sustainability Science', Science's Compass, 292(April), pp. 641-642.

Kim, A. M. (2013) Sidewalk City. Chicago, US: The University of Chicago Press. doi: 10.7208/chicago/9780226119366.001.0001.

Kleine, A. (2009) Operationalisierung einer Nachhaltigkeitsstrategie: Ökologie, Ökonomie und Soziales integrieren. Springer-Verlag.

Knippenberg, L. et al. (2007) 'Developing tools for the assessment of sustainable development in the 
province of Brabant, the Netherlands', Sustainability Indicators-Scientific Assessment, pp. 309-328.

Kyle, G. T., Jun, J. and Absher, J. D. (2014) 'Repositioning Identity in Conceptualizations of Human-Place Bonding', Environment and Behavior, 46(8), pp. 1018-1043. doi: 10.1177/0013916513488783.

de la Torre, M. I. (2015) 'Espacio público y colectivo social', Nova Scientia, 14(7), pp. 495-510.

Lara-Hernandez, J. A., Melis, A. and Caputo, S. (2017) 'Understanding Spatial Configuration and Temporary Appropriation of the Street in Latin American cities: the case of Mexico City Centre', in Scavone, V. et al. (eds) Urban Planning and Architectural Design for Sustainable Development (UPADSD). Palermo, Italy: IEREK, pp. 153-173.

Lawrence, D. L. and Low, S. M. (1990) 'The Built Environment And Spatial Form', Annual Review of Anthropology, 19(1), pp. 453-505. doi: 10.1146/annurev.anthro.19.1.453.

Leary-Owhin, M. (2015) 'A Fresh Look at Lefebvre's Spatial Triad and Differential Space: A Central Place in Planning Theory?’, in 2nd Planning Theory Conference University of the West of England, pp. 1-8.

Lefebvre, H. (1971) De lo rural a lo urbano, Ediciones Península. Edited by J. Gonzalez-Pueyo. Barcelona, España: Ediciones Peninsula.

Lefebvre, H. (1992) The Production of the Space. 1996th edn. Cambridge, Massachusetts: Blackwell Publishers Ltd.

Lehmann, S. (2015) 'Low Carbon Cities: More than just Buildings', in Lehmann, S. (ed.) Low Carbon Cities: Transforming Urban Systems, pp. 1-56.

Lofland, L. H. (1998) The public realm: Exploring the city's quintessential social territory. New York, US: Transaction Publishers.

Loukaitou-Sideris, A. and Ehrenfeucht, R. (2009) Sidewalks: Conflict and Negotiation over Public Space. Cambridge, Massachusetts: Mit Press.

Lozano, R. (2008) 'Envisioning sustainability three-dimensionally', Journal of Cleaner Production, 16(17), pp. 1838-1846. doi: 10.1016/j.jclepro.2008.02.008.

MacDonald, R. and Shildrick, T. (2007) 'Street Corner Society: Leisure Careers, Youth (Sub)culture and Social Exclusion', Leisure Studies, 26(3), pp. 339-355. doi: 10.1080/02614360600834826.

Madanipour, A. (1996) Design of urban space. An inquiry into socio-spatial process. New York, US: John Wiley \& Sons, Inc.

Martínez, E. (2014) ‘Configuración urbana, hábitat y apropiación del espacio’, Scripta Nova. Revista electrónica de geografia y ciencias sociales. Barcelona, España, XVIII(493), p. 20.

Maslow, A. H. (1943) 'A theory of human motivation', Psychological review. American Psychological Association, 50(4), p. 370.

Mehan, A. (2016) 'Urban Regeneration: A Comprehensive Strategy for Achieving Social Sustainability in Historical Squares', in 3rd International Multidisciplinary Scientific Conference on Social Sciences and Arts. SGEM INTERNATIONAL MULTIDISCIPLINARY SCIENTIFIC CONFERENCE ON SOCIAL SCIENCES AND ARTS, pp. 861-868. doi: 10.5593/sgemsocial2016HB42.

Mehan, A. and Soflaei, F. (2017) 'Social sustainability in urban context', in Architectural Research Addressing Societal Challenges. CRC Press, pp. 293-299. doi: doi:10.1201/9781315226255-47.

Monnet, J. (1995) Usos e imágenes del centro histórico de la Ciudad de México. Edited by Centro de estudios mexicanos y centroamericanos.

Moudon, A. V. (1991) Public Streets for Public Use. New York, US: Columbia University Press.

Mouffe, C. (2014) Agonística. Pensar el mundo políticamente. Edited by S. Laclau. Mexico, DF: Fondo de Cultura Económica de Argentina.

Munasinghe, M. (1993) Environmental economics and sustainable development. World Bank Publications. Neher, A. (1991) 'Maslow's Theory of Motivation: A Critique', Journal of Humanistic Psychology, 31(3), pp. 89-112. doi: 10.1177/0022167891313010.

Noschis, K. et al. (1978) 'Appropriation of space: a method and two case studies', Ekistics, 45(273), pp. 451466.

Opp, S. M. (2017) 'The forgotten pillar: a definition for the measurement of social sustainability in American cities', Local Environment. Taylor \& Francis, 22(3), pp. 286-305. doi: 10.1080/13549839.2016.1195800. 
Oxford University (2018) culture | Definition of culture in English by Oxford Dictionaries. Available at: https://en.oxforddictionaries.com/definition/culture (Accessed: 22 January 2018).

Oxford University Press (2015) Oxford English Dictionary Online, Oxford English Dictionary. Available at: http:/ / dictionary.oed.com (Accessed: 12 May 2015).

Pol, E. (2002) 'The theoretical background of the City-Identity-Sustainability Network', Environment \& Behavior, 34(1), pp. 8-25.

Pol, E. and Iñiguez, L. (1996) 'La Apropiacion del Espacio’, Monografías Psicosoaicles Ambientales, 9.

Pol Urrútia, E. (2002) 'El modelo dual de la apropiación del espacio en Mira, R., Sabucedo, JM y Romay, J.', Psicología y Medio Ambiente. Aspectos psicosociales, educativos y metodológicos, pp. 123-132.

Pongsmas, N. (2004) Configuration of public space and social sustainability of urban neighborhood: A case study of the city of San Diego at the dawn of the twenty-first century. Texas Tech University. Available at: https://ttu-ir.tdl.org/ttu-ir/handle/2346/19502.

Portal, M. A. (2009) 'Las creencias en el asfalto . La sacralización como una forma de apropiación del espacio público en la ciudad de México', Cuadernos de Antropología Social, (30), pp. 59-75.

Purcell, M. (2002) 'Excavating Lefebvre: The right to the city and its urban politics of the inhabitant', GeoJournal, 58, pp. 99-108. doi: 10.1023/B:GEJO.0000010829.62237.8f.

Raman, S. (2010) 'Designing a liveable compact city physical forms of city and social life in urban neighbourhoods', Built Environment, 36(1), pp. 63-80. doi: 10.2148/benv.36.1.63.

Ramirez-Lovering, D. (2008) Opportunistic urbanism. Melbourne, Australia: RMIT Press.

Rapoport, A. (1998) 'Using “Culture” in Housing Design', in Housing and Society. Seul, Korea, pp. 1-20.

Rapoport, A. (2005) Culture, Architecture, and Design. Chicago: Locke Science Publisher.

Relph, E. (1976) Place and placelessness. 2nd edn. Pion Limited.

Seaman, J. and McLaughlin, S. (2014) 'The importance of outdoor activity and place attachment to adolescent development in Coös County, New Hampshire', Building knowledge for families and communities. Carsey Institute. Available at: http://scholars.unh.edu/carsey/208/.

Seghezzo, L. (2009) 'The five dimensions of sustainability', Environmental Politics, 18(4), pp. 539-556. doi: 10.1080/09644010903063669.

Sharifi, A. and Murayama, A. (2013) 'A critical review of seven selected neighborhood sustainability assessment tools’, Environmental Impact Assessment Review, 38, pp. 73-87. doi: 10.1016/j.eiar.2012.06.006.

Shirazi, M. R. and Keivani, R. (2017) 'Critical reflections on the theory and practice of social sustainability in the built environment - a meta-analysis’, Local Environment. Taylor \& Francis, 0(0), pp. 1-20. doi: 10.1080/13549839.2017.1379476.

Simpson, P. (2011) 'Street Performance and the City: Public Space, Sociality, and Intervening in the Everyday', Space and Culture, 14(4), pp. 415-430. doi: 10.1177/1206331211412270.

Spindler, E. (2011) 'Geschichte der Nachhaltigkeit Vom Werden und Wirken eines beliebten Begriffes', Edmund A. Spindler, p. 21.

Torres, E. (2009) 'Apropiación Versus Usos Del Espacio Público'. Available at: https://www.mardelplata.gob.ar/documentos/policia/taller 1 cultura y territorio apuntes.pdf (Accessed: 1 November 2017).

Turnbull, C. M. (1974) ‘The Mountain People’. New York, US: Simon \& Schuster.

Valentin, A. and Spangenberg, J. H. (2000) 'A guide to community sustainability indicators', Environmental Impact Assessment Review, 20(3), pp. 381-392. doi: 10.1016/S0195-9255(00)00049-4.

Vallance, S., Perkins, H. C. and Dixon, J. E. (2011) 'What is social sustainability? A clarification of concepts', Geoforum. Elsevier Ltd, 42(3), pp. 342-348. doi: 10.1016/j.geoforum.2011.01.002.

Vidal Moranta, T. and Pol Urrútia, E. (2005) 'La apropiación del espacio: Una propuesta teórica para comprender la vinculación entre las personas y los lugares', Anuario de Psicologia, 36(3), pp. 281-297. doi: 10.1006/jevp.2000.0185.

Vojnovic, I. (2014) 'Urban sustainability: Research, politics, policy and practice', Cities. Elsevier Ltd, 41, pp. S30-S44. doi: 10.1016/j.cities.2014.06.002.

Woodcraft, S. (2012) 'Social Sustainability and New Communities: Moving from Concept to Practice in the 
UK', Procedia - Social and Behavioral Sciences. Elsevier B.V., 68, pp. 29-42. doi: 10.1016/j.sbspro.2012.12.204.

Woodcraft, S. (2015) 'Understanding and measuring social sustainability', Journal of Urban Regeneration \& Renewal, 2, pp. 133-144. Available at:

http://www.ingentaconnect.com/content/hsp/jurr/2015/00000008/00000002/art00004.

Yiftachel, O. and Hedgcock, D. (1993) 'Urban social sustainability', Cities, 10(2), pp. 139-157. doi: 10.1016/0264-2751(93)90045-K.

Yory, M. C. (2011) 'El Concepto de Topofilia entendido como Teoría del Lugar', Revista Barrio Taller, pp. 117.

Yory García, C. M. (2003) Topofilia, ciudad, territorio: una estrategia pedagógica de desarrollo urbano participtivo con dimensión sustentable para las grandes metrópolis de América Latina en el contexto de la globalización: 'el caso de la ciudad de Bogotá'. Universidad Complutense de Madrid. Available at: http://biblioteca.ucm.es/tesis/ghi/ucm-t26725.pdf. 